\title{
PERSEPSI PETANI TERHADAP PEMBUKAAN LAHAN TANPA PEMBAKARAN (PLTB) DI KELURAHAN SAGATANI KECAMATAN SINGKAWANG SELATAN
}

\author{
(Farmers' Perceptions Of Land Clearing Without Burning (Pltb) In Sagatani Kelurahan \\ Singkawang Selatan District)
}

\author{
Sri Widarti, Donna Youlla, Icuk Setiawan \\ Program Studi Agribisnis, Universitas Panca Bhakti \\ Jl. Kom. Yos Sudarso Pontianak \\ Penulis Koresponden: sriwidarti1373@gmail.com,
}

Article Submitted: 19-11-2021

Article Accepted: 07-01-2022

\begin{abstract}
People's perceptions of land clearing by burning are still diverse, there are pros and cons about it. As we all know, the land clearing system by slashing and burning is a heritage and culture of farming communities in almost all parts of Indonesia, one of them is the people of the island of Kalimantan. Several solutions have been proposed by the government, including land clearing without burning (PLTB). This program aims to change the behaviour of Indonesian farmers who still do land clearing by burning to switch to more environmentally friendly land clearing methods, including converting slashes into compost and wood vinegar. However, until now several programs launched by the government in order to minimize the forest and land fires have not been successful. Increasing the production of hybrid corn commodities is one of the targets for increasing agricultural productivity in West Kalimantan, especially in Singkawang in meeting the demand for hybrid corn which is currently supplied from outside the city. The increase in production cannot be separated from the need for expansion of hybrid corn farming land, which currently the number and focus of increasing hybrid corn farming businesses are in Sagatani Village, South Singkawang District. Problems arise when in their business, hybrid corn farmers in Sagatani Village still use conventional methods in cleaning and clearing land, namely by burning.
\end{abstract}

Keywords : Land clearing without burning (PLTB), Hybrid Corn, Perception

\section{PENDAHULUAN}

Potensi pengembangan sektor pertanian di Provinsi Kalimantan Barat sangat besar karena Kalimantan Barat memiliki lahan yang sangat luas dibandingkan provinsi lainnya di Indonesia.D ari potensi luas lahan pertanian 1,19 juta Ha, Kalimantan Barat baru memanfaatkan areal pertanian sebesar 380.000 Ha. Namun hingga saat ini luasan lahan tersebut tidak dikelola dengan baik dan maksimal. Beberapa program yang diluncurkan oleh pemerintah untuk meningkatkan usaha pertanian antara lain penyediaan fasilitas dan kemudahan bagi anak muda untuk beraktivitas di sektor pertanian, penyediaan lahan dan fasilitas sarana produksi, aplikasi teknologi dan menjamin pemasaran

Berkaitan dengan usaha peningkatan produktifitas pertanian tentulah membutuhkan ketersediaan lahan sebagai media tanam dan penyiapan lahan baru sebagai langkah awal untuk memulai 
budidaya tanaman pertanian. Telah menjadi momok tahunan, dan mungkin juga merupakan sebuah tradisi bahwa penyiapan lahan selalu dilakukan dengan cara dibakar.

Persepsi masyarakat terhadap pembukaan lahan dengan cara dibakar masih beragam, ada pro dan kontra didalamnya. Seperti diketahui bersama, sitem pembukaan lahan dengan cara tebas dan dibakar merupakan warisan dan budaya masyarakat petani hampir diseluruh wilayah Indonesia, salah satunya masyarakat pulau Kalimantan. Dalam beberapa penelitian, diantaranya yang meneliti cara berladang masyarakat Dayak Kantuk, Kabupaten Kapuas Hulu, Kalimantan Barat (Michael,1988).Dalam penelitiannya disebutkan berladang dengan sistem tebas-tebang-bakar sebagai strategi adaptasi orang Kantuk terhadap alamnya. Hutan hujan tropis mempengaruhi tingkat keasaman tanah cukup tinggi. Beberapa keuntungan yang diperoleh menurut masyarakat Dayak dari sistem pertanian tebas bakar antara lain mengurangi kadar asam tanah dan menambah hara atau kesuburan tanah, maka sistem tebas-tebangbakar dianggap sangat cocok dan baik di tanah Kalimantan (Aseanty, 2017).

Salah satu alternatifnya adalah teknik pembukaan lahan tanpa bakar, dengan berbagai variasinya (Onrizal, 2005). Karena investasi yang mahal untuk teknik pembukaan lahan tanpa bakar, maka masyarakat belum mau untuk mengaplikasikannya sehingga pembukaan lahan dengan cara di bakar masih terus terjadi.

Beberapa solusi telah dicanangkan oleh pemerintah diantaranya adalah pembukaan lahan tanpa bakar (PLTB). Program ini bertujuan untuk mengubah prilaku para petani Indonesia yang masih melakukan pembukaan lahan dengan cara dibakar untuk beralih cara pembukaan lahan yang lebih ramah lingkungan diantaranya dengan mengubah tebasan menjadi pupuk kompos dan cuka kayu. Akan tetapi, hingga saat ini beberapa program yang dicanangkan oleh pemerintah untuk meminimalisir kejadian kebakaran hutan dan lahan dapat dikatakan belum berhasil.

Jagung hibrida merupakan komoditas pertanian yang sangat gencar di kembangkan di provinsi Kalimantan Barat. Hal ini disebabkan karena kabutuhan jagung dan jumlah produksi jagung di Kaliamntan Barat yang masih tidak seimbang. Sebagai contoh, Kota Singkawang membutuhkan jagung dalam tahun 2018 sebanyak 10 ribu ton dan sebanyak 5 ribu ton dipenuhi dari kabupaten Sanggau (Hendri, 2019). Jagung hibrida adalah jenis jagung keturunan lansung (F1) hasil persilangan 2 (dua) atau lebih varietas jagung yang memiliki sifat unggul dari masing-masing varietas yang disilangkan. Sifat unggul yang ditawarkan biasanya mampu bertongkol 2 (dua), ukuran biji dan tongkol lebih besar, masa panen lebih singkat dan keunggulan lainnya. Jagung hibrida boiasanya digunakan sevagai campuran utama bahan pakan ternak.

Sebagai salah satu kota yang gencar mengembangkan produksi jagung, Kota Singkawang telah berusaha semaksimal mungkin untuk meningkatkan produksi jagung untuk pemenuhan kebutuhan lokal yang masih disuplai dari luar daerah mulai dari penyediaan lahan, subsidi benih, pupuk dan peralatan pendukung. Kecamatan Singkawang Selatan merupakan salah satu sentra penghasil jagung hibrida di Kota Singkawang (Kantor Ketahanan Pangan dan Penyuluhan Pertanian Kota Singkawang, 2019). Kecamatan Singkawang Selatan memiliki luasan lahan pertanian jagung sebesar $275 \mathrm{Ha}$. Komoditas jagung tersebut terbagi menjadi $70 \mathrm{Ha}$ pertanian jagung manis dan 205 Ha pertanian jagung hibrida.

Dari seluruh lahan pertanian jagung hibrida tersebut, berdasarkan hasil diskusi dengan petugas Penyuluh Lapangan (PPL) Kelurahan Sagatani dan Ketua Gabungan Kelompok Tani Kelurahan Sagatani, menerangkan bahwa seluruh petani jagung di Kelurahan Sagatani masih menerapkan pembersihan dan penyiapan lahan dengan 
dibakar yang mana pembersihan lahan dengan cara dibakar tersebut tidak selaras dengan anjuran pemerintah. Walaupun tidak menghasilkan kebakaran yang besar, namun asap yang ditimbulkan menjadi salah satu penyumbang polusi udara. Pembakaran dilakukan untuk membersihkan sisa batang jagung, daun dan kelobot jagung pasca panen. Hal tersebut dilakukan dikarenakan para petani belum memiliki solusi yang tepat, cepat dan murah dalam penyiapan lahan.Selain cepat, bersih dan murah, dengan pembakaran lahan petani berharap abu sisa pembakaran dapat digunakan sebagai tambahan penyubur tanah. Masyarakat umumnya yang tinggal di sekitar hutan yang mempunyai pekerjaan dibidang pertanian mempunyai hubungan yang erat dengan lingkungannya.

Disamping itu masyarakat mengenal sikap dan pola fikir serta bertindak masih berpegang teguh pada norma, adat serta tradisi yang diwarisi secara turun menurun. Oleh karenanya aspek sosial sangat berperan penting dalam pengambilan keputusan para petani dalam kehidupan kesehariannya, termasuk dalam usaha pengelolaan pertanian.

Dari keterangan Ketua Gapoktan Kelurahan Sagatani juga didapatkan informasi bahwa program pembukaan lahan tanpa bakar secara khusus belum pernah dilakukan di Kecamatan Singkawang Selatan. Penyuluhan pengendalian kebakaran hanya sampai tahap pengenalan Program PLTB, belum pada aplikasi program.

Dari uraian tersebut diatas diketahui bahwa perkembangan pertanian jagung hibrida di Kota Singkawang terbesar berada di Kelurahan Sagatani, yang mana keseluruhan petani jagung tersebut masih melakukan pembakaran dalam penyiapan lahan. Usaha peningkatan produktifitas pertanian jagung hibrida yang akan didorong oleh pemerintahan Kota Singkawang akan berdampak buruk bagi lingkungan, jika usaha tersebut tidak dibarengi dengan perubahan paradigma pembersihan dan pembukaan lahan dengan cara dibakar.

\section{METODE PENELITIAN}

Populasi dalam penelitian ini adalah seluruh petani tanaman jagung hibrida, di Kelurahan Sagatani Kecamatan Singkawang Selatan Kota Singkawang yaitu sebanyak 273 petani yang ada di Kelurahan tersebut yang terdata oleh Penyuluh Pertanian Lapangan (PPL). Jumlah sampel responden yang digunakan dalam penelitian sebanyak 41 orang yang dipilih secara acak.

Untuk mengukur tingkat persepsi petani jagung hibrida ditinjau dari aspek sosial terhadap pembukaan lahan dengan cara dibakar di Kelurahan Sagatani Kecamatan Singkawang Selatan Kota Singkawang dilakukan dengan menggunakan teknik skoring terhadap beberapa indikator, yaitu (1) umur; (2) pendidikan petani; (3) pengalaman petani; (4) Hubungan antar warga sesama petani; (5) Partisipasi petani dalam mencegah kebakaran lahan; dan (6) Sikap petani terhadap aturan larangan pembukanan lahan dengan cara dibakar.

\section{HASIL DAN PEMBAHASAN}

\section{A. Karakte ristik Responden}

1. Umur Responden

Dari data karakteristik responden dapat disimpulkan bahwa petani jagung di Kelurahan Sagatani didominasi oleh petani dalam kelas umur diatas 45-62 tahun yaitu berjumlah 23 responden atau 56,10\% dari jumlah seluruh responden, yang dapat diartikan bahwa petani jagung di Kelurahan sagatani dalam usia produktif.

2. Tingkat Pendidikan Responden

Tingkat pendidikan petani jagung di Kelurahan Sagatani terbanyak berada pada jenjang pendidikan tidak tamat SD-SD yaitu berjumlah 19 responden atau setara 46,34\% dari seluruh responden.

3. Luas Lahan Responden 
Luas lahan pertanian dari keterangan responden di Kelurahan Sagatani terbanyak berada pada rentang 0,1-1,73 Ha dengan jumlah pengelola sejumlah 37 responden atau setara 90,24\% dari jumlah responden 4. Jumlah Tanggungan Keluarga Responden Hampir keseluruhan petani di Kelurahan Sagatani menggantungkan kehidupannya dari hasil pertanian sebagai mata pencaharian utama, walupun ada beberapa yang memiliki kegiatan sampingan lain seperti berdagang. Sebagai sumber pencaharian utama, maka kebutuhan keluarga sangat bergantung dari hasil panen yang diperoleh dari usaha pertanian. Untuk Kelurahan Sagatani jumlah tanggungan keluarga petani jagung rata-rata berada pada rentang 4-6 jiwa yang dimiliki oleh 29 responden petani jagung atau setara $70,73 \%$ dari seluruh jumlah populasi responden.

\section{B. Persepsi petani (aspek sosial) terhadap pembukaan lahan dengan cara dibakar}

Sugihartono (2007), mengemukakan bahwa persepsi adalah kemampuan otak dalam menerjemahkan stimulus atau proses untuk menerjemahkan stimulus yang masuk ke dalam alat indera manusia. Pengukuran persepsi petani jagung hibrida di Kelurahan Sagatani, yang keselurahan petani menerapkan metode pembersihan lahan dengan cara membakar ditinjau dari aspek sosial dengan beberapa variabel pengukuran yaitu umur, pendidikan, pengalaman, hubungan antar warga sesama petani dan partisipasi petani dalam mencegah kebakaran lahan.

Tabel 1. Data rekapitulasi persepsi petani jagung hibrida terhadap pembukaan lahan dengan cara dibakar ditinjau dari aspek sosial

\begin{tabular}{|c|c|c|c|c|}
\hline No & Variabel & $\bar{S}$ & $\overline{\mathrm{RR}}$ & TS \\
\hline 1 & Umur & & & \\
\hline 1.1 & Mempengaruhi kemampuan olah lahan & 87 & 0 & 12 \\
\hline 1.2 & Mempengaruhi produksi & 36 & 6 & 26 \\
\hline 1.3 & Mempengaruhi biaya penyiapan lahan & 102 & 6 & 4 \\
\hline 1.4 & Mempengaruhi adopsi informasi dan inovasi & 54 & 6 & 20 \\
\hline 1.5 & Mempengaruhi pengalaman & 123 & 0 & 0 \\
\hline 2 & Pendidikan & & & \\
\hline 2.1 & Mempengaruhi penerimaan informasi dan inovasi & 48 & 4 & 23 \\
\hline 2.2 & Mempengaruhi kemampuan olah lahan & 33 & 8 & 26 \\
\hline 2.3 & Mempengarui jumlah produksi & 18 & 6 & 32 \\
\hline 2.4 & Mempengaruhi adopsi informasi dan inovasi & 48 & 0 & 25 \\
\hline 3 & Pengalaman petani & & & \\
\hline 3.1 & $\begin{array}{l}\text { Penyiapan lahan dengan pembakaran merupakan } \\
\text { tindakan turun-temurun }\end{array}$ & 120 & 0 & 1 \\
\hline 3.2 & Pembakaran lebih baik dari tanpa bakar & 108 & 4 & 3 \\
\hline 3.3 & $\begin{array}{l}\text { Pembakaran lebih menguntungkan dari tanpa } \\
\text { bakar }\end{array}$ & 108 & 4 & 3 \\
\hline 4 & Hubungan antar warga sesama petani & & & \\
\hline 4.1 & Kebersamaan dalam menyiapkan lahan & 60 & 16 & 13 \\
\hline 4.2 & Persamaan metode dalam penyiapan lahan & 39 & 4 & 27 \\
\hline 4.3 & Waktu penyiapan lahan & 36 & 2 & 28 \\
\hline 4.4 & Penerimaan masukan dari luar (pendatang) & 96 & 12 & 4 \\
\hline
\end{tabular}




\begin{tabular}{|c|c|c|c|c|}
\hline 5 & Partisipasi petani dalam mencegah kebakaran lahan & & & \\
\hline 5.1 & Kepedulian terhadap kejadian kebakaran lahan & 123 & 0 & 0 \\
\hline 5.2 & Kearifan lokal dalam mencegah kebakaran & 123 & 0 & 0 \\
\hline 5.3 & Pentingnya satuan pengendalian kebakaran & 48 & 2 & 24 \\
\hline 5.4 & $\begin{array}{l}\text { Pentingnya intrumen peraturan untuk penyiapan } \\
\text { lahan dengan dibakar }\end{array}$ & 75 & 2 & 15 \\
\hline 5.5 & $\begin{array}{l}\text { Keinginan untuk terlibat dalam pelatihan } \\
\text { pencegahan kebakaran }\end{array}$ & 54 & 6 & 20 \\
\hline
\end{tabular}

6 Sikap petani terhadap aturan

1.1 Pembakaran dalam penyiapan lahan harus dilarang

1.2 Hukuman terhadap pembakar berupa penjara dan denda

1.3 Pelaku pembakaran harus di hukum adat 54

1.4 Pembakaran lahan seharusnya diijinkan

1.5 Pembakaran lahan diatur dalam peraturan desa 111

15

$6 \quad 10$

54

1.6 Penerapan aturan dipisah antara petani dan 75 3 korporas

\begin{tabular}{lc}
\hline Rata-rata jumlah & 2,09 \\
\hline Jumlah total rata-rata & 13,37 \\
\hline Rerata skor & 2,23 \\
\hline
\end{tabular}

Berdasarkan rekap skor pada tabel 1. di atas maka faktor umur memiliki nilai 2,35 sehingga persepsi responden dari aspek sosial item umur dikategorikan setuju, karena berada pada interval >2,34 -3 . Hasil dari penilaian aspek sosial item pendidikan memiliki rata-rata nilai skoring 1,65 atau dapat diinterpretasikan berada dalam kategori tidak setuju, karena berada pada interval $1-1,67$. Selanjutnya hasil penilaian aspek sosial item pengalaman petani memiliki rata-rata nilai skoring 2,85 atau dapat diinterpretasikan berada dalam kategori setuju, karena berada pada interval $>2,34$ - 3. Untuk hasil penilaian aspek sosial item hubungan antar warga petani memiliki rata-rata nilai skoring 2,04 atau dapat diinterpretasikan berada dalam kategori ragu-ragu, karena berada pada interval $>1,67$ - 2,34. Untuk hasil penilaian aspek sosial item partisipasi petani dalam mencegah kebakaran lahan memiliki rata-rata nilai skoring 2,40 atau dapat diinterpretasikan berada dalam kategori setuju, karena berada pada interval $>2,34-3$. Kemudian hasil penilaian sikap petani terhadap aturan larangan pembakaran lahan memiliki ratarata nilai skoring 2,09 atau dapat diinterpretasikan berada dalam kategori ragu-ragu, karena berada pada interval $>1,67$ $-2,34$.

Hasil rekapitulasi terhadap seluruh komponen persepsi yaitu umur, pendidikan, pengalaman, hubungan antar warga petani, partisipasi petani dalam mencegah kebakaran lahan dan sikap petani terhadap aturan larangan pembakaran lahan menghasilkan skor penilaian sebesar 2,23 atau dapat diinterpretasikan bahwa persepsi petani jagung hibrida terhadap pembukaan lahan dengan cara dibakar ditinjau dari aspek sosial di Kelurahan Sagatani Kecamatan Singkawang berada pada kategori ragu-ragu karena berada pada interval skoring $>1,67-2,34$. 
Pernyataan tersebut dikarenakan dapat dikatakan seluruh petani jagung hibrida di Kelurahan Sagatani masih menerapkan pembakaran lahan, walaupun dalam tahun 2020 ketua gapoktan sedang berusaha memberi contoh praktek Pembukaan Lahan Tanpa Bakar (PLTB) di lahannya kepada petani di Kelurahan Sagatani namun tidak ada petani yang ingin mengikuti contoh tersebut. Petani cenderung memilih sikap tidak patuh terhadap aturan walaupun mengetahui resikonya, namun masyarakat juga tetap tidak ingin merasakan kompensasi hukum (dipenjara dan denda) akibat pembakaran lahan yang masih mereka terapkan.

Masyarakat petani di Kelurahan Sagatani pada dasarnya sangat patuh terhadap segala aturan pemerintah yang berlaku, namun ketiadaan solusi atau pilihan lain menyebabkan masyarakat mengenal sikap dan pola fikir serta bertindak masih berpegang teguh pada norma, adat serta tradisi yang diwarisi secara turun menurun sehingga cara tradisonal tetap dilakukan karena masyarakat menginginkan kebebasan berusaha, utamanya dalam bidang pertanian dengan berbagai metode yang dianggap lebih praktis dan menguntungkan. Petani menginginkan adanya solusi berupa peraturan desa yang mengatur berkaitan dengan tata cara dalam pembukaan lahan dengan cara membakar seperti pemberlakuan jadwal bakar dan luasan yang setidaknya diperbolehkan untuk dilakukan pembersihan dengan cara dibakar.

Keinginan tersebut berkaitan dengan adanya Peraturan Gubernur Kalimantan Tengah Nomor 15 Tahun 2010 Tentang Pedoman Pembukaan Lahan dan Pekarangan Bagi Masyarakat di Kalimantan Tengah dimana di dalam peraturan tersebut memberikan kebijakan memperbolehkan pembersihan lahan dengan cara membakar sebesar 1-2 Ha dengan syarat melaporkan kepada instansi terkait seperti Camat, Kepala Desa dan RT.
Contoh-contoh seperti kebijakan peraturan diatas yang sangat diinginkan masyarakat sebagai solusi tepat dalam menyelesaikan antara permasalahan pembukaan lahan dan permasalahan lingkungan. Keinginan tersebut selaras dengan keinginan penerapan peraturan yang berbeda, yaitu antara petani kecil dan perkebunan besar. Hal tersebut disebabkan adanya perasaan ketidakadilan yang dirasakan oleh masyarakat dengan perbandingan ladang kecil yang mereka kelola sebagai mata pencaharian untuk pemenuhan kehidupan sehari-hari dengan perkebunan besar tetapi penerapan aturan dan hukum diberlakukan sama oleh pemerintah.

\section{KESIMPULAN}

Persepsi petani jagung terhadap pembukaan lahan dengan cara dibakar ditinjau dari aspek sosial berdasarkan hasil rekapitulasi terhadap seluruh komponen persepsi yaitu umur, pendidikan, pengalaman, hubungan antar warga petani, partisipasi petani dalam mencegah kebakaran lahan dan sikap petani terhadap aturan larangan pembakaran lahan adalah 2,23 atau dikategorikan ragu-ragu, karena berada pada interval skoring >1,67 - 2,34. Sehingga dapat diinterpretasikan bahwa persepsi petani jagung hibrida terhadap pembukaan lahan dengan cara dibakar di Kelurahan Sagatani Kecamatan Singkawang masih menyatakan ragu-ragu aspek sosial menjadi penyebab masih dilakukannya pembukaan/penyiapan lahan dengan cara dibakar.

\section{DAFTAR PUSTAKA}

Aditiea Loren, Muhammad Ruslan, Fadly H. Yusran, Fonny Rianawati. 2015. Analisis Faktor Penyebab Kebakaran Hutan dan Lahan Serta Upaya Pencegahan yang Dilakukan Masyarakat di Kecamatan Basarang 
Kabupaten Kapuas Kalimantan Tengah. EnviroScienteae, 11, $1-9$.

Aseanty, Pahlevi. (2019). Bagi Masyarakat Dayak, Berladang Itu Sekaligus Menjaga Keragaman Hayati, https:// www.mongabay.co.id/2019/10/17/ba gi-masyarakat-dayak-berladang-itusekaligus-menjaga-keragamanhayati/. di akses pada tanggal 5 Februari 2020.

Candro Manalu. 2015. Persepsi Petani Padi Sawah Terhadap Program Pencetakan Lahan Sawah di Desa Singkep Kec. Muara Sabak Barat Kabupaten Tanjung Jabung Timur. Sosio Ekonomika Bisnis Vol 18. (1) 2015.

Hasyim, Hasman. 2003. Analisis Hubungan Faktor Sosial Ekonomi Petani Terhadap Program Penyuluhan Pertanian. Laporan Hasil Penelitian. Universitas Sumatera Utara, Medan.

Hendri, Chornelius. (2019). Sanggau Suplai Jagung Hibrida 18 ton ke Singkawang. https://pontianak.tribunnews.com/20 19/03/19/sanggau-suplai-jagunghibrida-18-ton-ke-singkawang. Diakses pada tanggal 5 Februari 2020.

M. Anang Firmansyah, Subowo. (2012). Dampak Kebakaran Lahan Terhadap Kesuburan Fisik, Kima, dan Biologi Tanah Serta Alternatif Penanggulangan dan Pemanfaatannya. Sumberdaya Lahan, 6(2), 1 - 12.

Onrizal. (2005). Pembukaan Lahan Dengan dan Tanpa Bakar. e-USU Repository,1-10.
Rahmad Dani, Defri Yoza, Rudianda Sulaeman. $2015 \quad$.Strategi Pemberdayaan Masyarakat dalam Penanggulangan Kebakaran Hutan dan Lahan di Kabupaten Rokan Hilir. Jom Faperta, 2(1), 1 - 12.

Rakhmat, Jalaludin. 2004. Psikologi Komunikasi. Bandung: PT. Remaja Rosdakarya.

Soekanto Soerjono. 2012. Sosiologi Suatu Pengantar. Jakarta : Rajawali Pers.

Soekartawi.1988. Prinsip dasar komunikasi pertanian. Jakarta : UI Press.

Soekartawi, 2003. Prinsip Ekonomi Pertanian. Rajawali Press. Jakarta.

Sugihartono, L. 2007. Psikologi Pendidikan. UNY Press. Yogyakarta.

Suharyanto dan I Ketut K. 2011. Kajian penerapan teknologi pupuk organik kascing di daerah sentra produksi sayuran Kabupaten Tabanan. Jurnal Pengkajian dan Pengembangan Teknologi Pertanian.Vol.14 (1): 28 -39 .

Syukri. 2015. Persepsi Petani Kelapa Sawit dari Aspek Sosial terhadap Pembakaran Lahan (Studi Kasus di Desa Tanjung Leban Kecamatan Kubu Kabupaten Rokan Hilir). Jom Faperta, 2(2), $1-8$.

Undang-Undang Republik Indonesia Nomor 39 Tahun 2014. 2014. Tentang Perkebunan.

Undang-Undang Nomor 32 Tahun 2009. 2009. Tentang Perlindungan dan Pengelolaan Lingkungan Hidup. 